Article

\title{
How Pre-Harvest Inactivated Yeast Treatment May Influence the Norisoprenoid Aroma Potential in Wine Grapes
}

\author{
Pasquale Crupi ${ }^{1, *}$, Marika Santamaria ${ }^{1}{ }^{\mathbb{D}}$, Fernando Vallejo ${ }^{2}$, Francisco A. Tomás-Barberán ${ }^{2}{ }^{\mathbb{D}}$, \\ Gianvito Masi ${ }^{1}$, Angelo Raffaele Caputo ${ }^{1}$, Fabrizio Battista ${ }^{3}\left(\mathbb{D}\right.$ and Luigi Tarricone ${ }^{1}$ \\ 1 CREA-VE, Council for Agricultural Research and Economics-Research Centre for Viticulture and Enology, \\ Via Casamassima 148, 70010 Turi (BA), Italy; marika.santamaria@crea.gov.it (M.S.); \\ gianvito.masi@crea.gov.it (G.M.); angeloraffaele.caputo@crea.gov.it (A.R.C.); luigi.tarricone@crea.gov.it (L.T.) \\ 2 CEBAS-CSIC, Centro de Edafología y Biología Aplicada del Segura, E-30100 Murcia, Spain; \\ fvallejo@cebas.csic.es (F.V.); fatomas@cebas.csic.es (F.A.T.-B.) \\ 3 LALLEMAND Italia, Via Rossini 14/B, 37060 Castel D'Azzano (VR), Italy; fbattista@lallemand.com \\ * Correspondence: pasquale.crupi@crea.gov.it; Tel.: +39-080-8915711
}

Received: 11 April 2020; Accepted: 6 May 2020; Published: 13 May 2020

\begin{abstract}
Carotenoids are important secondary metabolites in wine grapes and play a key role as potential precursors of aroma compounds (i.e., $\mathrm{C}_{13}$-norisoprenoids), which have a high sensorial impact in wines. There is scarce information about the influence of pre-harvest inactivated yeast treatment on the norisoprenoid aroma potential of grapes. Thus, this work aimed to study the effect of the foliar application of yeast extracts (YE) to Negro Amaro and Primitivo grapevines on the carotenoid content during grape ripening and the difference between the resulting véraison and maturity $(\Delta C)$. The results showed that $\beta$-carotene and (allE)-lutein were the most abundant carotenoids in all samples, ranging from $60 \%$ to $70 \%$ of total compounds. Their levels, as well as those of violaxanthin, $\left(9^{\prime} Z\right)$-neoxanthin, and 5,6-epoxylutein, decreased during ripening. This was especially observed in treated grapes, with $\Delta C$ values from 2.6 to 4.2 -fold higher than in untreated grapes. Besides this, a principal components analysis (PCA) demonstrated that lutein, $\beta$-carotene, and violaxanthin and $\left(9^{\prime} Z\right)$-neoxanthin derivatives principally characterized Negro Amaro and Primitivo, respectively. Thereby, the YE treatment has proved to be effective in improving the $\mathrm{C}_{13}$-norisoprenoid aroma potentiality of Negro Amaro and Primitivo, which are fundamental cultivars in the context of Italian wine production.
\end{abstract}

Keywords: HPLC-DAD-MS; 5,6-/5,8-epoxyxanthophylls; elicitors; pheophytins; chlorophylls

\section{Introduction}

The presence of carotenoids in grape berries is well documented [1]. 5,6-epoxyxanthophylls and their 5,8-epoxy isomers were identified together with the most common carotenes and xanthophylls (i.e., $\beta$-carotene and lutein), the content of which was established to decrease during grape ripening from véraison to harvest [2-4]. The grape variety and viticulture practices, but also climate conditions and geographic origin, can influence the qualitative and quantitative profile of carotenoids in berries [5-7].

Structurally, carotenoids are $\mathrm{C}_{40}$ tetraterpenoids with a long chromophore of conjugated double bonds; thus, they can confer from red to yellow coloration to fruit [8]. However, especially in $\mathrm{red} /$ black grapes, this function is ascribed to anthocyanins and polyphenols [9]. Instead, carotenoids are mainly known as precursors of volatile compounds (i.e., $\mathrm{C}_{13}$-norisoprenoids), with very low olfactory perception thresholds. Thus, they have a fundamental role in defining the varietal aroma of grapes and wines $[10,11] . \mathrm{C}_{13}$-norisoprenoids form by the direct enzymatic oxidation of carotenoids, such 
as $\beta$-carotene, lutein, neoxanthin, and violaxanthin, followed by the acid hydrolysis of glycosylated intermediates [12].

There is no standard extraction procedure of carotenoids from foodstuffs; generally, in the case of grapes, aprotic and poor-polarity organic solvents, such as acetone [2] or diethyl ether/hexane 1:1 [13], are employed to extract carotenes and xanthophylls simultaneously. Reversed-phase HPLC coupled with various detection techniques (e.g., DAD and MS) is currently the method of choice for carotenoid analysis [14]. In particular, the $C_{30}$ stationary phase has the highest separation selectivity including structural and geometrical isomers [15].

Currently, the vineyard application of elicitors (i.e., methyl jasmonate or yeast extracts) represents the most original strategy to activate the biosynthesis of secondary metabolites because it may stimulate an innate immune response in grapes $[16,17]$. Generally, it works in the case of the phenolic and volatile composition of grapes $[9,18,19]$, but recent research has demonstrated that treatment with methyl jasmonate and yeast extracts was also determinant for increasing lutein and $\beta$-carotene concentrations in Tempranillo, Graciano, and Garnacha [20]. Additionally, the enzymes involved in carotenoid biosynthesis and degradation are acknowledged to be stress-dependent [21,22].

A previous study conducted by our research group on carotenoid degradation during the grape ripening of four varieties (Chardonnay, Merlot, Primitivo, and Negro Amaro) in the Apulia region proposed a parameter $(\Delta C)$ to distinguish grapes with higher $\mathrm{C}_{13}$-norisoprenoid aroma potentiality. $\Delta \mathrm{C}(\mu \mathrm{g} / \mathrm{kg})$, calculated as the difference between the total carotenoid content at véraison and harvest, was lowest in the autochthonous Primitivo and Negro Amaro [7]. Considering the supposed effect of yeast extracts on carotenoids, their application to vineyards could be hypothesized to enhance $\Delta \mathrm{C}$ in grapes, although, to the best of our knowledge, no other reports exist in the literature about this property.

Therefore, this work aimed to assess the effectiveness of pre-harvest treatment by inactivated yeast extracts (YE) in improving the $\mathrm{C}_{13}$-norisoprenoid aroma potentiality of Apulian Negro Amaro and Primitivo varieties, which are fundamental in the context of Italian wine production.

\section{Materials and Methods}

\subsection{Plant Materials}

The experiment was conducted in 2019 on a 10 year-old commercial vineyard of Negro Amaro cv. located in the Salice Salentino wine grape area (Masseria Filippi, Apulia region, Southern Italy) and a 6 year-old commercial vineyard of Primitivo cv. located in the Gioia del Colle D.OC. (Denomination of Controlled Origin) area (Azienda Benagiano, Apulia region, Southern Italy). Both Negro Amaro and Primitivo vines, grafted onto Vitis berlandieri $\times$ Vitis rupestris 1103 Paulsen rootstock, were planted in north-south oriented rows; they were spaced $2.15 \mathrm{~m}$ between rows and $0.90 \mathrm{~m}$ on the row, trained to a Vertical Shoot Positioned (VSP) system and spur-pruned with 14 buds per vine.

The experimental design for the current study was a randomized complete block with four replicates, with three rows of each treatment ( 80 vines per row) separated by a buffer row. Treatment consisted in two canopy spraying times, the first at the beginning of veráison $(5 \%)$ and the second 12 days later, with Lalvigne ${ }^{\circledR}$ MATURE diluted in water without adjuvant at $1 \mathrm{~kg} / \mathrm{ha}$ dose (YE) in comparison to untreated rows used as control (C). Lalvigne ${ }^{\circledR}$ MATURE is a formulation of $100 \%$ natural inactivated wine yeast (Saccharomyces cerevisiae) derivatives, non-pathogenic, non-hazardous, food grade and non-GMO, which are specifically designed to be used with the patented foliar application technology WO/2014/024039 (Lallemand Inc., Montreal, QC, Canada).

A random sample of three bunches for each repetition was manually picked between the third and seventh node from random vines at periodic intervals from August until September. Berries $(\sim 30 \mathrm{~g})$ were then chosen at random from these bunches and stored in the dark at $-80{ }^{\circ} \mathrm{C}$ until analysis. 


\subsection{Chemicals}

HPLC-grade hexane and acetone were purchased from J.T. Baker (Deventer, Holland). LCMS grade water, methanol and tert-butyl-methyl-ether were purchased from Chromasolv (Exacta+Optech Labcenter S.p.A., Modena, Italy). Sodium hydroxide $(\mathrm{NaOH}) 0.1 \mathrm{~N}$ and bromothymol blue were purchased from Sigma Aldrich (Merck Life Science S.r.l., Milano, Italy). $\beta$-apo-8'-carotenal and 3-tert-butyl-4-hydroxyanisole (BHA) were purchased from Fluka (Exacta+Optech Labcenter S.p.A., Modena, Italy). $\beta$-carotene and magnesium carbonate basic were purchased from Sigma-Aldrich (Merck Life Science S.r.l., Milano, Italy); (allE)-lutein and zeaxanthin were obtained from Extrasynthese (Genay, France), whereas ( $9^{\prime} Z$ )-neoxanthin, violaxanthin, 5,6-epoxide-lutein, and (9Z)- $\beta$-carotene were obtained from CaroteNature (Münsingen, Switzerland) and used as HPLC reference standards.

\subsection{Maturation Indexes of Grapes}

Total soluble solids (TSS), titratable acidity (TA), and $\mathrm{pH}$ were determined according to protocols established by the OIV, 1990 [23]. Berries were crushed to determine the TSS (expressed as $\mathrm{g} / \mathrm{L}$ ) of berry juice using a portable refractometer (ATAGO PR32). TA (as $\mathrm{g} / \mathrm{L}$ of tartaric acid equivalents) was also determined for the juice by titrating with $0.1 \mathrm{~N}$ sodium hydroxide to the bromothymol blue end point. Finally, juice $\mathrm{pH}$ was measured by the $\mathrm{pH}$ meter CRISON BASIC 20.

\subsection{Extraction of Carotenoids from Grapes}

The carotenoid extraction procedure was adapted from the method of Crupi et al. 2010 [4]. Approximately $30 \mathrm{~g}$ of freeze berries containing $25 \mu \mathrm{L}$ of BHA $(12.66 \mathrm{mg} / \mathrm{mL}$ in EtOH) were crushed in an IKA A11 basic homogenizer (IKA, WERKE GMBH \& CO.KG, Staufen, Germany) for 5 min in the presence of magnesium carbonate basic ( 2 to $4 \mathrm{~g}$ for mature and green berries, respectively). The homogenate was diluted with $40 \mathrm{~mL}$ of distillated water and spiked with $100 \mu \mathrm{L}$ of internal standard $\left(150 \mu \mathrm{g} / \mathrm{mL}\right.$ of $\beta$-apo- $8^{\prime}$-carotenal). Extraction was done with $40 \mathrm{~mL}$ of hexane/diethyl ether $(1: 1, v / v)$ by agitating the mixture for $30 \mathrm{~min}$. The resulting upper layer was separated by centrifugation at $4000 \mathrm{rpm}$ and $4^{\circ} \mathrm{C}$ for $1 \mathrm{~min}$ (EPPENDORF 5810R, Eppendorf AG, Hamburg, Germany). The extraction procedure was repeated twice for the lower phase using $20 \mathrm{~mL}$ of hexane/diethyl ether $(1: 1, v / v)$. The pooled extract was evaporated to dryness using a rotovapor Buchi-R-205. The residue was dissolved in $2 \mathrm{~mL}$ of acetone/hexane $(1: 1, v / v)$, filtered through $0.20 \mu \mathrm{m}$ syringe PTFE filters and stored at $-20^{\circ} \mathrm{C}$ until the carotenoid analysis by HPLC-DAD-MS.

\subsection{HPLC-DAD-MS Analyses of Carotenoids}

HPLC-DAD-MS analyses were carried out with an Agilent model 1100 equipped with quaternary pump solvent delivery, a thermostated column compartment, diode array detector, and XCT-trap mass detector (Agilent Technologies, Palo Alto, CA, USA). A positive electrospray mode was used for the ionization of molecules with acquisition of mass spectra between $\mathrm{m} / \mathrm{z} 100$ and 1200, capillary voltage at $-4000 \mathrm{~V}$, and skimmer voltage at $30 \mathrm{~V}$. The reversed stationary phase employed was a YMC pack $C_{30}$ (YMC Inc., Wilmington, NC, USA) $5 \mu \mathrm{m}\left(250 \times 3 \mathrm{~mm}\right.$ i.d.) with a precolumn $\mathrm{C}_{30} 5 \mu \mathrm{m}$ $\left(20 \times 3 \mathrm{~mm}\right.$ i.d.). The following gradient system was used with $\mathrm{H}_{2} \mathrm{O}$ (solvent $\mathrm{A}$ ), methanol (solvent $\mathrm{B}$ ), and tert-butyl methyl ether (solvent C): 0 min, \%A-\%B-\%C, 40-60-0; $5 \mathrm{~min}, \% \mathrm{~A}-\% \mathrm{~B}-\% \mathrm{C}, 20-80-0$; $10 \mathrm{~min}, \% \mathrm{~A}-\% \mathrm{~B}-\% \mathrm{C}, 4-81-15 ; 60 \mathrm{~min}, \% \mathrm{~A}-\% \mathrm{~B}-\% \mathrm{C}, 4-11-85 ; 65 \mathrm{~min}, \% \mathrm{~A}-\% \mathrm{~B}-\% \mathrm{C}, 4-11-85 ; 70 \mathrm{~min}$, $\% \mathrm{~A}-\% \mathrm{~B}-\% \mathrm{C}, 40-60-0$. Stop time at $70 \mathrm{~min}$ with a re-equilibration time of $20 \mathrm{~min}$ corresponding to ca 3.0 column volumes $\left(\mathrm{Vc}=1.3 \mathrm{~mL}\right.$ ). The column was kept at $20^{\circ} \mathrm{C}$, the flow was maintained at $0.2 \mathrm{~mL} / \mathrm{min}$, and the sample injection volume was $3 \mu \mathrm{L}$. Diode array detection was between 250 and $700 \mathrm{~nm}$ and absorbance was recorded at $447 \mathrm{~nm}$. Positive electrospray mode was used for the ionization of molecules with a capillary voltage at $-4000 \mathrm{~V}$ and skimmer voltage at $40 \mathrm{~V}$. The nebulizer pressure was $15 \mathrm{psi}$ and the nitrogen flow rate was $5 \mathrm{~L} / \mathrm{min}$. The temperature of drying gas was $350{ }^{\circ} \mathrm{C}$. In the full scan mode, the monitored mass range was from $\mathrm{m} / \mathrm{z} 100$ to 1200 . MS ${ }^{2}$ was performed by 
using helium as the collision gas at a pressure of $4.6 \times 10^{-6} \mathrm{mbar}$. Collision induced dissociation (CID) spectra were obtained with an isolation width of $4.0 \mathrm{~m} / \mathrm{z}$ for precursor ions and a fragmentation amplitude of $0.6 \mathrm{~V}$ for epoxyxanthophylls, and $1.0 \mathrm{~V}$ for the other carotenoids.

Compound identification was achieved by combining different information: the positions of absorption maxima $\left(\lambda_{\max }\right)$, the degree of vibration fine structure (\% III/II), the ratio of the absorbance of the cis peak to the absorbance of the second absorption band in the visible region, known as the $\mathrm{Q}$ ratio or $\mathrm{D}_{\mathrm{B}} / \mathrm{D}_{\mathrm{II}}[8,24]$, and the capacity factor values $\mathrm{k}^{\prime}$ and mass spectra were compared with those from pure standards and interpreted with the help of structural models already hypothesized in the literature (such as $(9 Z)$ or $\left(9^{\prime} Z\right)$-lutein and the other lutein-like structures reported in Table 1 , which were only tentatively identified) [4].

Table 1. HPLC-DAD-MS $\left(\mathrm{ESI}^{+}\right)$characteristics of carotenoids in grapes.

\begin{tabular}{|c|c|c|c|c|c|c|c|c|}
\hline Peak & Compound & $\mathbf{k}^{\prime}$ & $\lambda_{\max }(\mathrm{nm})$ & $\begin{array}{c}\% \\
(\mathrm{III} / \mathrm{II})^{\mathrm{a}} \\
\end{array}$ & $\mathrm{D}_{\mathrm{B}} / \mathrm{D}_{\mathrm{II}}^{\mathrm{b}}$ & {$[\mathrm{M}+\mathrm{H}]^{+}(\mathrm{m} / \mathrm{z})$} & {$[\mathrm{M}]^{+}(\mathrm{m} / \mathrm{z})$} & $\begin{array}{c}\mathrm{MS}^{2} \text { Product } \\
\text { Ions m/z }\end{array}$ \\
\hline 1 & $\begin{array}{l}\text { violaxanthin like } \\
\text { structure }\end{array}$ & 2.78 & $418 ; 440 ; 470$ & 84 & & 601.5 & $\underline{600.1}$ & $\begin{array}{c}583.5,565.5 \\
509.5,491.5 \\
221.1\end{array}$ \\
\hline 2 & violaxanthin & 2.92 & $416 ; 440 ; 468$ & 86 & & 601.5 & 600.1 & $\begin{array}{c}583.5,565.5 \\
509.5,491.5 \\
221.1\end{array}$ \\
\hline 3 & (8'R)-neochrome & 3.01 & $400 ; 422 ; 450$ & 88 & & 601.5 & 600.1 & $\begin{array}{l}583.2,565.3, \\
509.5,221.1\end{array}$ \\
\hline 4 & $\left(9^{\prime} Z\right)$-neoxanthin & 3.06 & $414 ; 436 ; 464$ & 86 & & 601.5 & 600.1 & $\begin{array}{l}583.2,565.3 \\
509.5,221.1\end{array}$ \\
\hline 5 & (8'S)-neochrome & 3.12 & $400 ; 422 ; 450$ & 88 & & 601.5 & 600.1 & $\begin{array}{l}583.2,565.3 \\
509.5,221.1\end{array}$ \\
\hline 6 & 5,6-epoxylutein & 3.19 & $416 ; 440 ; 468$ & 90 & & 585.4 & $\underline{584.2}$ & $\begin{array}{c}567.1,493.1 \\
221.1\end{array}$ \\
\hline 7 & luteoxanthin & 3.33 & $399 ; 422 ; 448$ & 94 & & 601.5 & 600.1 & $583.2,221.1$ \\
\hline 8 & $\begin{array}{l}\text { lutein like } \\
\text { structure }\end{array}$ & 3.42 & $\begin{array}{c}(425) ; 446 ; \\
474\end{array}$ & & & 568.9 & 567.9 & $\begin{array}{l}550.9,532.9, \\
476.4,429.4\end{array}$ \\
\hline 9 & $\begin{array}{l}\text { Z lutein like } \\
\text { structure }\end{array}$ & 3.47 & $\begin{array}{l}328 ;(412) ; \\
436 ; 464\end{array}$ & & & 568.9 & 567.9 & $\begin{array}{l}550.9,532.9, \\
476.4,429.4\end{array}$ \\
\hline 10 & $\left(8^{\prime} S\right)$-auroxanthin & 3.64 & $380 ; 402 ; 426$ & 98 & & 601.5 & $\underline{600.1}$ & $\begin{array}{c}583.5,565.5 \\
509.5,491.5 \\
221.1\end{array}$ \\
\hline 11 & chlorophyll b & 3.70 & $\begin{array}{l}258 ; 314 ; 342 ; \\
466 ; 600 ; 650\end{array}$ & & & & & \\
\hline 12 & (allE)-lutein & 3.75 & $\begin{array}{l}(422) ; 446 ; \\
\quad 472\end{array}$ & 40 & & 568.9 & 567.9 & $\begin{array}{l}550.9,532.9, \\
476.4,429.4\end{array}$ \\
\hline 13 & zeaxanthin & 4.00 & $\begin{array}{c}(425) ; 452 \\
476\end{array}$ & 22 & & 568.9 & 567.9 & $\begin{array}{l}550.9,532.9, \\
476.4,429.4\end{array}$ \\
\hline 14 & $\begin{array}{c}(9 Z) \text { or } \\
\left(9^{\prime} Z\right) \text {-lutein }\end{array}$ & 4.16 & $\begin{array}{c}330 ;(422) \\
440 ; 468\end{array}$ & 50 & 0.075 & 568.9 & 567.9 & $\begin{array}{l}550.9,532.9, \\
476.4,429.4\end{array}$ \\
\hline 15 & chlorophyll a & 4.31 & $\begin{array}{l}336 ;(385) ; \\
(417) ; 432 ; \\
618 ; 665\end{array}$ & & & & & \\
\hline IS & $\beta$-apo- $8^{\prime}$-carotenal & 4.50 & 460 & & & & & \\
\hline 16 & pheophytin $b$ & 5.46 & $\begin{array}{c}(417) ; 436 ; \\
527 ; 600 ; 654\end{array}$ & & & & 885 & \\
\hline 17 & pheophytin a & 5.59 & $\begin{array}{c}410 ; 506 ; 536 \\
666\end{array}$ & & & & 871 & \\
\hline 18 & $\beta$-carotene & 5.98 & $\begin{array}{c}(430) ; 452 \\
478\end{array}$ & 25 & & 536.9 & 535.9 & $\frac{444.2,430.3}{399.3}$ \\
\hline 19 & (9Z)- $\beta$-carotene & 6.25 & $\begin{array}{c}342 ;(424) ; \\
446 ; 474\end{array}$ & 17 & 0.03 & 536.9 & 535.9 & $\frac{444.2,430.3}{399.3}$ \\
\hline
\end{tabular}

$a \% \mathrm{III} / \mathrm{II}$ is the ratio of the height of the longest-wavelength absorption peak, designated III, and that of the middle absorption peak, designated as II, taking the minimum between the two peaks as a baseline [8]; ${ }^{b}$ The $Q$ ratio is the quotient between the cis peak band and band II (normally $\lambda_{\text {max. }}$ ) [24]. The fragments corresponding to the base peak in $\mathrm{MS}^{2}$ spectra were underlined. 
To evaluate linearity, calibration curves with seven concentration points for each compound were prepared separately. Calibration was performed by a linear regression of peak-area ratios of the carotenoids to the internal standard ( $\beta$-apo- 8 -carotenal) versus the respective standard concentration. The precision of the method was determined by calculating the intraday and interday repeatability, expressed as standard deviation (SD) ( $\sigma$ ) and relative standard deviation (RSD) in terms of retention times and peak width $\left(\mathrm{W}_{1 / 2}\right)$, by the injection of four different replicates of extracts on the same day or over three consecutive days. The detection limit (LOD) and quantification limit (LOQ) were calculated on the basis of the calibration curve of low concentrations of target compounds and defined as $\operatorname{LOD}=3^{*}(\mathrm{Syx} / \mathrm{b})$ and LOQ $=10^{*}(\operatorname{Syx} / \mathrm{b})$, where $\mathrm{b}$ is the slope and Syx is the standard error of the calibration curve (Supplementary Materials, Table S1).

Depending on the type of chemical structure, carotenoids were quantified as $\mu \mathrm{g}$ violaxanthin (in the case of violaxanthin and a violaxanthin-like structure), (9'Z)-neoxanthin (in the case of (9'Z)-neoxanthin, $\left(8^{\prime} \mathrm{R}\right)$-neochrome, (8S)-neochrome, and auroxanthin), 5,6-epoxylutein (in the case of 5,6-epoxylutein and luteoxanthin), (allE)-lutein (in the case of (allE)-lutein, (9Z)-lutein, and lutein-like structures), zeaxanthin (in the case of zeaxanthin), and $\beta$-carotene (in the case of $\beta$-carotene and (9Z)- $\beta$-carotene) equivalents per $\mathrm{kg}$ of berries.

\subsection{Statistical Analysis}

Data were analyzed by the STATISTICA 8.0 (StatSoft Inc., Tulxa, OK, USA, 2012) software package. Specifically, after testing their normal distribution by Shapiro-Wilk's W test together with their homoscedasticity by means of the Levene test, a two-way multivariate analysis of variance (MANOVA) was performed for the HPLC-DAD-quantified carotenoids in order to evaluate the effects of the factors "treatment" and "ripening" on each cultivar. The Tukey HSD post hoc test was used to separate the means $(p<0.05)$ when the interaction between the factors was significant.

Finally, a principal components analysis (PCA) was performed on variables corresponding to the difference between the values of the identified carotenoids at véraison and maturity to cluster samples per treatment. The PCA was done on the correlation matrix in order to treat all variables on an equal footing, in consecutive steps (as reported by Martì et al. 2004 [25]) and starting from those variables which were shown to be significant through the MANOVA.

\section{Results and Discussion}

\subsection{Carotenoid Composition of the Wine Grape Varieties}

Nineteen compounds including carotenoids (15), chlorophylls (2), and pheophytins (2) were detected by HPLC-DAD-MS in the wine grape extracts (Figure 1).

It is worth noting that consistency in carotenoid attribution is very complex due to their structural diversity. In particular, the double bond-conjugated system is susceptible to heat, light, oxygen, and acids, giving rise to unwanted cis-trans isomerization. Using antioxidants (i.e., BHA), an ice bath, and minimizing the light exposition of the samples during the extraction steps are mandatory to prevent the formation of cis-isomers as artifact compounds [26]. Therefore, alongside the main trans carotenoids identified, $\beta$-carotene and (allE)-lutein, accounting for $60 \%$ and $70 \%$ of total carotenoids in mature Primitivo and Negro Amaro grapes [7], we were also confident that the cis-isomers (assigned as 9Z-lutein and 9Z- $\beta$-carotene) were present in the grape tissue (Table 1).

Analogously, an acidic medium could cause the isomerization of 5,6-epoxyxanthophylls (Figure 2). Indeed, treating an acetone/hexane solution of violaxanthin and $\left(9^{\prime} Z\right)$-neoxanthin $(3 \mu \mathrm{g} / \mathrm{mL})$ with $500 \mu \mathrm{L}$ of tartaric acid $(15 \mathrm{~g} / \mathrm{L})$ at a concentration similar to that of green berries, hypsochromic shifts of their absorption maxima ( $\lambda \max$ ) of $20 \mathrm{~nm}$ (corresponding to the generation of luteoxanthin and neochrome) and $40 \mathrm{~nm}$ (corresponding to the generation of auroxanthin) were observed within $30 \mathrm{~min}$ (Figure 3). Thanks to the addition of $\left(\mathrm{MgCO}_{3}\right) 4 \mathrm{Mg}(\mathrm{OH})_{2} 5 \mathrm{H}_{2} \mathrm{O}$, which neutralized the extraction solution, we could exclude that the recognized 5,8-epoxyxanthophylls, $\left(8^{\prime} \mathrm{R}\right)$-neochrome (peak 3$)$, 
$\left(8^{\prime} S\right)$-neochrome (peak 5), luteoxanthin (peak 7) and auroxanthin (peak 10), were derived from the isomerization of violaxanthin (peak 2 ) and ( $9^{\prime} Z$ )-neoxanthin (peak 4), respectively, during the extraction (Table 1).

Furthermore, the absence of flavoxanthin and chrysantemaxanthin, originating from 5,6-epoxylutein (Figure 2), also confirmed this speculation. Although the lack of these two xanthophylls appeared to disagree with our past report [4], it is worth noting that the carotenoid composition is often influenced by climate and viticulture practices, such as trellis systems [27].

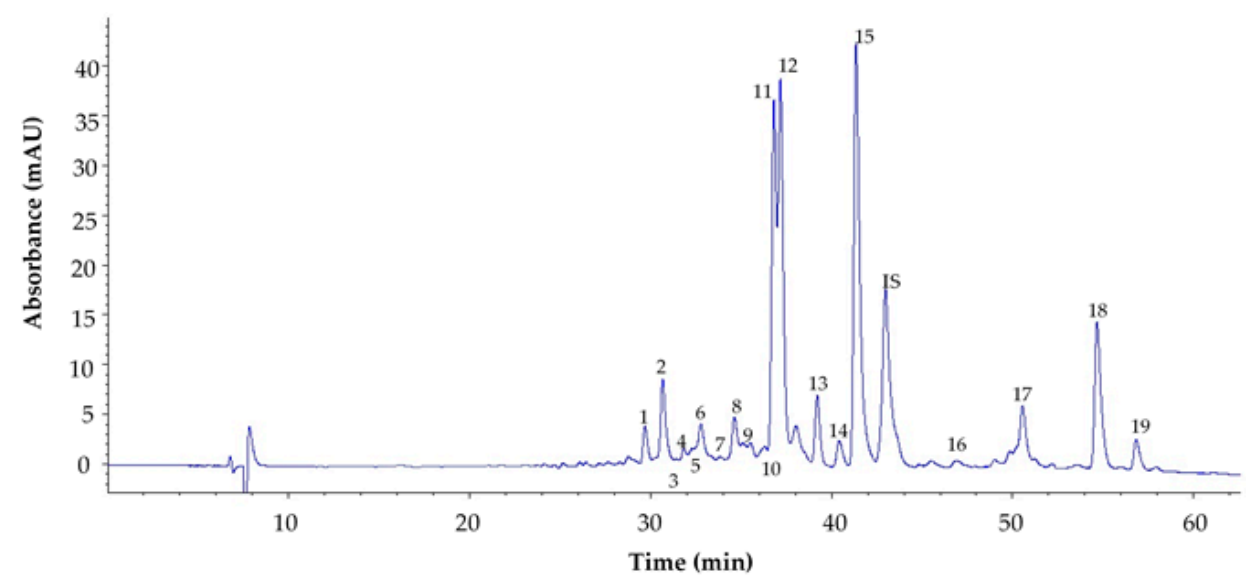

Figure 1. HPLC-DAD profile of carotenoids in mature grapes (Primitivo $c v)$. Peaks: (1) violaxanthin-like structure; (2) violaxanthin; (3) (8'R)-neochrome; (4) (9'Z)-neoxanthin; (5) (8'S)-neochrome; (6) 5,6-epoxylutein; (7) luteoxanthin; (8) lutein-like structure; (9) $Z$ lutein-like structure; (10) (8'S)-auroxanthin; (11) chlorophyll b; (12) (allE)-lutein; (13) zeaxanthin; (14) (9Z) or (9'Z)-lutein; (15) chlorophyll a; (16) pheophytin b; (17) pheophytin a; (18) $\beta$-carotene; (19) (9Z)- $\beta$-carotene. IS $\beta$-apo- $8^{\prime}$-carotenal.

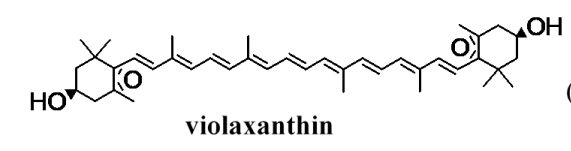

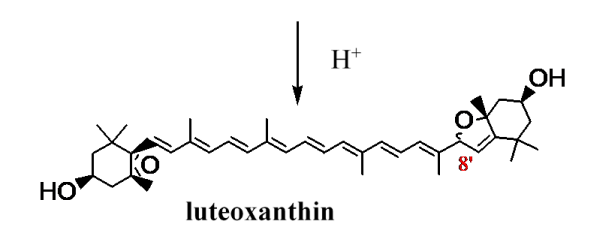<smiles>CC1CC(O)C(C)CC1=O</smiles>

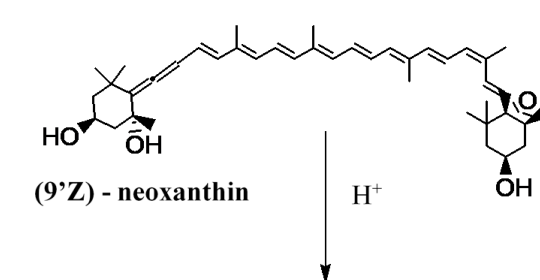

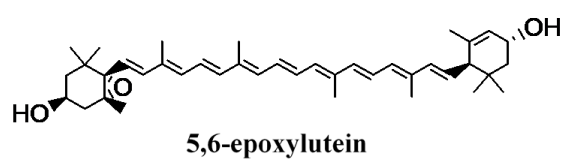

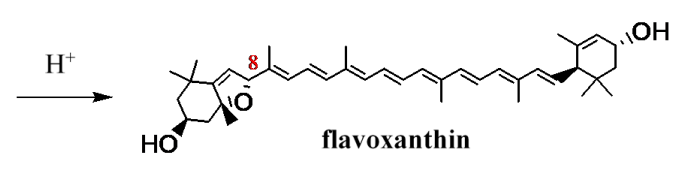

(c)

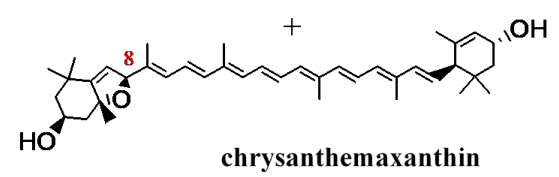

Figure 2. Acid-catalyzed isomerization of (a) violaxanthin, (b) (9'Z)-neoxanthin, and (c) 5,6-epoxylutein. 

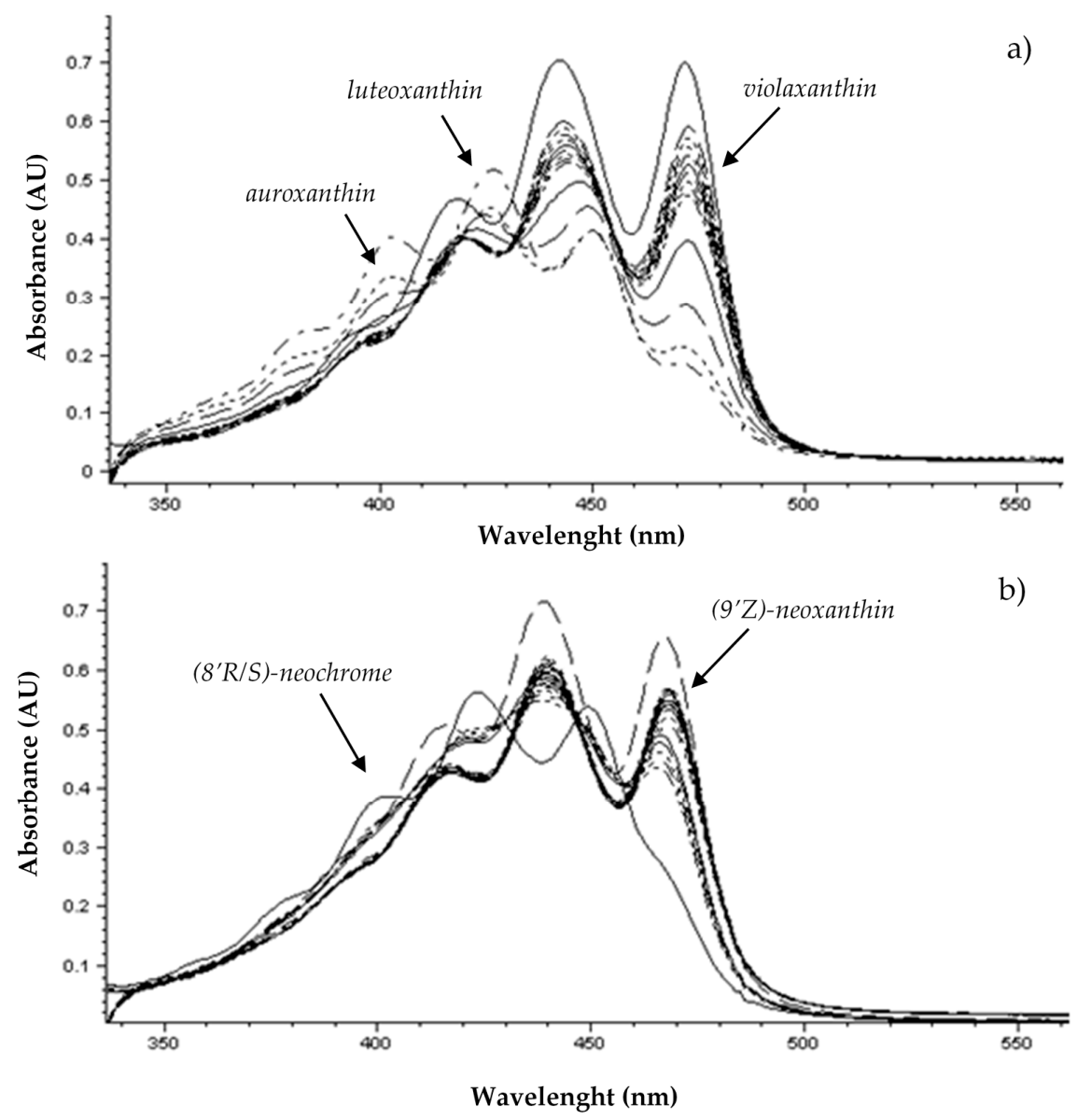

Figure 3. UV-Vis spectra of (a) violaxanthin and (b) $\left(9^{\prime} \mathrm{Z}\right)$-neoxanthin $(3 \mu \mathrm{g} / \mathrm{mL})$ treated with tartaric acid (15 g/L).

\subsection{Effect of Pre-Harvest YE Application on Carotenoid Content}

According to the choice of the main figures of merit reported elsewhere [28], the adopted HPLC-DAD method was validated for the target analysis of carotenoids in terms of linearity, LOD, LOQ, and precision (Supplementary Materials, Table S1). The calibration curves were obtained by the internal standard method to give determination coefficients $\left(R^{2}\right)$ which were higher than 0.99 ; moreover, the detection and quantification limits were found to be under 2 and $5 \mu \mathrm{g} / \mathrm{kg}$, respectively. As regards precision tests, intra-assay and inter-assay coefficients of variation were calculated, with retention times ranging between $0.11 \%$ and $0.13 \%$, and $0.37 \%$ and $0.50 \%$, respectively, while corresponding measures for $\mathrm{W}_{1 / 2}$ were between $2.9 \%$ and $15 \%$, and $2.8 \%$ and $12 \%$, respectively. These results confirmed the accuracy and reproducibility of data obtained by the analytical method for carotenoid analysis.

Tables 2 and 3 listed the changes in carotene and xanthophyll concentrations (expressed in $\mu \mathrm{g} / \mathrm{kg}$ of berries) during the grape ripening of the two varieties, Negro Amaro and Primitivo, in control and YE-treated samples. As expected, total carotenoids significantly decreased from véraison to maturity, even more consistently in Negro Amaro ( $\mathrm{F}=34.06, p<0.001)$, due to the higher accumulation of the compounds in the first sampling date, respective to Primitivo $(\mathrm{F}=19.54, p<0.001)$ (Figure 4$)$. Regarding the effect of the elicitor (YE), the treatment factor (T) as well as its interaction with ripening (TxR) resulted in a more pronounced effect in the variation of total carotenoid content in Primitivo (T: $\mathrm{F}=29.11, p<0.001$; TxR: $\mathrm{F}=7.06, p<0.001$ ) than Negro Amaro (T: $\mathrm{F}=5.55, p=0.0047 ; \mathrm{TxR}: \mathrm{F}=6.05$, $p=0.0021)$. This difference was mostly influenced by the anomalous behavior of the P0813 control sample; the lowest carotenoid value could be ascribed to an experimental drawback that occurred during the sampling and/or extraction phase, as suggested by the extraction yields in the four replicates, which were low (Supplementary Materials, Figure S1). 
Table 2. Changes in carotenoid contents (expressed as $\mu \mathrm{g} / \mathrm{kg}$ of berries) in Negro Amaro grapes from véraison to maturity.

\begin{tabular}{|c|c|c|c|c|c|c|c|c|c|c|c|}
\hline & \multirow[t]{2}{*}{ Sampling Date } & \multicolumn{2}{|c|}{$08 / 13 / 19^{*}$} & \multicolumn{2}{|c|}{$08 / 26 / 19$} & \multicolumn{2}{|c|}{$09 / 02 / 19$} & \multicolumn{2}{|c|}{$09 / 17 / 19$} & \multicolumn{2}{|c|}{$\Delta \mathrm{C}^{\mathrm{a}}$} \\
\hline & & C & $\mathrm{YE}$ & $\mathrm{C}$ & $\mathrm{YE}$ & C & $\mathrm{YE}$ & C & $\mathrm{YE}$ & $\mathrm{C}$ & $\mathrm{YE}$ \\
\hline & TSS $^{b}$ & $153.0^{c} \pm 1.7^{d}$ & $142.3 \pm 1.2$ & $165 \pm 2$ & $163 \pm 2$ & $171.4 \pm 1.4$ & $189 \pm 1.0$ & $212 \pm 3$ & $220 \pm 3$ & & \\
\hline & $\mathrm{pH}$ & $3.11 \pm 0.01$ & $3.17 \pm 0.01$ & $3.10 \pm 0.02$ & $3.26 \pm 0.01$ & $3.31 \pm 0.06$ & $3.38 \pm 0.04$ & $3.36 \pm 0.04$ & $3.43 \pm 0.06$ & & \\
\hline & $\mathbf{T A}^{e}$ & $8.47 \pm 0.15$ & $7.78 \pm 0.16$ & $6.25 \pm 0.18$ & $5.82 \pm 0.10$ & $5.63 \pm 0.07$ & $6.6 \pm 0.4$ & $5.8 \pm 0.3$ & $5.4 \pm 0.4$ & & \\
\hline & TSS/TA ${ }^{\mathrm{f}}$ & $18.1 \pm 0.4$ & $18.3 \pm 0.5$ & $26.4 \pm 1.1$ & $27.9 \pm 0.4$ & $30.4 \pm 0.2$ & $29 \pm 3$ & $37 \pm 2$ & $40 \pm 3$ & & \\
\hline \multicolumn{12}{|l|}{ Compounds } \\
\hline violaxanthin like structure ${ }^{g}$ & & $30 \pm 5 c^{h}$ & $64 \pm 15 \mathrm{a}$ & $49 \pm 5 \mathrm{ab}$ & $34 \pm 5 b c$ & $39 \pm 6 \mathrm{bc}$ & $42 \pm 7 \mathrm{bc}$ & $34 \pm 5 b c$ & $29 \pm 4 \mathrm{c}$ & & \\
\hline violaxanthing & & $96 \pm 10 \mathrm{~b}$ & $126 \pm 14 \mathrm{a}$ & $80 \pm 12 b c$ & $67 \pm 10 \mathrm{c}$ & $91 \pm 14 \mathrm{bc}$ & $97 \pm 15 b$ & $79 \pm 12 \mathrm{bc}$ & $68 \pm 9 c$ & & \\
\hline$\left(8^{\prime} \mathrm{R}\right)$-neochrome ${ }^{i}$ & & $8.2 \pm 0.6 \mathrm{a}$ & $9.5 \pm 0.3 \mathrm{a}$ & $8.5 \pm 0.8 \mathrm{a}$ & $4.8 \pm 1.0 \mathrm{~b}$ & $3.2 \pm 0.6 \mathrm{c}$ & $4.2 \pm 0.4 \mathrm{bc}$ & $2.8 \pm 0.5 c$ & $2.95 \pm 0.17 \mathrm{c}$ & & \\
\hline$\left(9^{\prime} \mathrm{Z}\right)$-neoxanthin ${ }^{i}$ & & $38 \pm 10 \mathrm{ab}$ & $56 \pm 10 \mathrm{a}$ & $58 \pm 12 a$ & $50 \pm 8 \mathrm{ab}$ & $47 \pm 13 \mathrm{ab}$ & $45 \pm 6 a b$ & $39 \pm 7 \mathrm{ab}$ & $31 \pm 3 b$ & & \\
\hline$\left(8^{\prime} S\right)$-neochrome ${ }^{i}$ & & $6.0 \pm 0.9 b$ & $9 \pm 2 \mathrm{a}$ & $7.3 \pm 1.3 \mathrm{ab}$ & $6.2 \pm 1.1 \mathrm{bc}$ & $4.6 \pm 0.7 \mathrm{c}$ & $5.5 \pm 0.8 \mathrm{bc}$ & $4.0 \pm 0.6 c$ & $3.8 \pm 0.5 c$ & & \\
\hline 5,6-epoxy-lutein ${ }^{l}$ & & $68 \pm 5 a$ & $82 \pm 8 \mathrm{a}$ & $53 \pm 9 b$ & $39 \pm 6 b c$ & $44 \pm 7 \mathrm{bc}$ & $43 \pm 6 b c$ & $38 \pm 6 \mathrm{bc}$ & $30 \pm 3 c$ & & \\
\hline luteoxanthing & & $8.8 \pm 1.2 \mathrm{~b}$ & $14 \pm 2 \mathrm{a}$ & $8.2 \pm 1.0 \mathrm{bc}$ & $7.6 \pm 1.5 b c$ & $9.0 \pm 1.0 \mathrm{~b}$ & $5.8 \pm 0.8 c$ & $7.8 \pm 0.9 \mathrm{bc}$ & $\operatorname{tr}$ & & \\
\hline lutein like structure ${ }^{m}$ & & $44 \pm 7 b$ & $62 \pm 5 a$ & $34 \pm 5 b c$ & $32 \pm 5 b c d$ & $29 \pm 6 \mathrm{~cd}$ & $29 \pm 7 \mathrm{~cd}$ & $25 \pm 6 \mathrm{~cd}$ & $20 \pm 4 d$ & & \\
\hline$Z$ lutein like structure ${ }^{m}$ & & $9.8 \pm 0.8 \mathrm{~b}$ & $14.9 \pm 1.8 \mathrm{a}$ & tr & tr & $5.9 \pm 1.2 \mathrm{c}$ & $4.1 \pm 1.8 \mathrm{~cd}$ & $5.1 \pm 1.1 \mathrm{~cd}$ & $2.8 \pm 1.2 \mathrm{~d}$ & & \\
\hline$\left(8^{\prime} \mathrm{S}\right)$-auroxanthing & & $54 \pm 7 \mathrm{a}$ & $68 \pm 15 a$ & $29 \pm 5 b$ & $10 \pm 3 c$ & $19 \pm 8 \mathrm{bc}$ & $18 \pm 3 b c$ & $15 \pm 5 b c$ & $12 \pm 2 b c$ & & \\
\hline (all-E)-lutein ${ }^{m}$ & & $600 \pm 90 b$ & $780 \pm 60 a$ & $570 \pm 90 \mathrm{bc}$ & $490 \pm 90 \mathrm{bcd}$ & $410 \pm 60 \mathrm{~cd}$ & $390 \pm 70 \mathrm{~d}$ & $360 \pm 60$ de & $200 \pm 20 \mathrm{e}$ & & \\
\hline zeaxanthin $^{n}$ & & $88 \pm 4$ & $101 \pm 5$ & $65 \pm 9$ & $65 \pm 15$ & $30 \pm 5$ & $28 \pm 4$ & $26 \pm 5$ & $20 \pm 2$ & & \\
\hline (9Z)-lutein ${ }^{m}$ & & $17 \pm 5 c$ & $33 \pm 5 a$ & $30 \pm 6 a b$ & $20 \pm 5 b c$ & $10 \pm 3 d$ & $11 \pm 3 \mathrm{~cd}$ & $9 \pm 2 d$ & $7 \pm 2 \mathrm{~d}$ & & \\
\hline$\beta$-carotene ${ }^{o}$ & & $390 \pm 60 \mathrm{bc}$ & $420 \pm 30 \mathrm{abc}$ & $390 \pm 60 \mathrm{bc}$ & $310 \pm 60 c$ & $550 \pm 90 \mathrm{a}$ & $390 \pm 60 \mathrm{bc}$ & $470 \pm 80 \mathrm{ab}$ & $270 \pm 40 c$ & & \\
\hline$(9 Z)-\beta$-carotene ${ }^{o}$ & & $130 \pm 50$ & $110 \pm 20$ & $180 \pm 50$ & $150 \pm 40$ & $230 \pm 20$ & $167 \pm 19$ & $200 \pm 20$ & $116 \pm 8$ & & \\
\hline Total $^{p}$ & & $1600 \pm 170 \mathrm{ab}$ & $1950 \pm 90 \mathrm{a}$ & $1600 \pm 200 \mathrm{ab}$ & $1280 \pm 180 \mathrm{~b}$ & $1500 \pm 200 b$ & $1280 \pm 180 \mathrm{~b}$ & $1320 \pm 170 b$ & $820 \pm 30 c$ & $270 \pm 300$ & $1130 \pm 120$ \\
\hline
\end{tabular}

${ }^{a}$ Difference of total carotenoid concentrations between véraison and maturity. ${ }^{b}$ Total soluble solids are expressed in $g / \mathrm{L} \cdot{ }^{c}$ Means of three replicates; ${ }^{d}$ Standard deviation at $p \leq 0.05$; ${ }^{e}$ Total acidity expressed in $\mathrm{g} / \mathrm{L}$ as tartaric acid. $f^{f}$ Maturation index; ${ }^{g}$ Expressed as violaxanthin equivalent; ${ }^{h}$ Different letters in the same line are significantly different at the $5 \%$ level (Tukey's Honestly Significant Difference test); ${ }^{i}$ Expressed as ( $\left(9^{\prime} Z\right.$ )-neoxanthin equivalent; ${ }^{l}$ Expressed as 5,6-epoxy-lutein equivalent; ${ }^{m}$ Expressed as (allE)-lutein equivalent; ${ }^{n}$ Expressed as zeaxanthin equivalent; ${ }^{\circ}$ Expressed as $\beta$-carotene equivalent; ${ }^{p}$ Sum of identified carotenoids. ${ }^{*}$ veraison: phenologic phase $10 \%$ of berries softening and/or coloring. tr: Present at a concentration lower than the limit of quantification (LOQ). 
Table 3. Changes in carotenoid contents (expressed as $\mu \mathrm{g} / \mathrm{kg}$ of berries) in Primitivo grapes from véraison to maturity.

\begin{tabular}{|c|c|c|c|c|c|c|c|c|c|c|c|}
\hline & \multirow[t]{2}{*}{ Sampling Date } & \multicolumn{2}{|c|}{$08 / 13 / 19$} & \multicolumn{2}{|c|}{$08 / 26 / 19^{*}$} & \multicolumn{2}{|c|}{$09 / 04 / 19$} & \multicolumn{2}{|c|}{$09 / 19 / 19$} & \multicolumn{2}{|c|}{$\Delta \mathrm{C}^{\mathrm{a}}$} \\
\hline & & C & YE & C & YE & $\mathrm{C}$ & YE & C & YE & C & YE \\
\hline & TSS $^{b}$ & $175^{c} \pm 1.0^{d}$ & $170 \pm 2$ & $187 \pm 1.5$ & $200 \pm 2$ & $226 \pm 4$ & $227 \pm 14$ & $236 \pm 5$ & $239 \pm 15$ & & \\
\hline & $\mathrm{pH}$ & $2.98 \pm 0.02$ & $2.97 \pm 0.03$ & $3.19 \pm 0.02$ & $3.22 \pm 0.02$ & $3.40 \pm 0.01$ & $3.35 \pm 0.08$ & $3.45 \pm 0.01$ & $3.40 \pm 0.07$ & & \\
\hline & $\mathbf{T A}^{e}$ & $11.2 \pm 0.4$ & $13.1 \pm 0.6$ & $6.8 \pm 0.3$ & $7.03 \pm 0.15$ & $6.2 \pm 0.4$ & $6.7 \pm 0.3$ & $5.7 \pm 0.4$ & $6.1 \pm 0.4$ & & \\
\hline & $\mathrm{TSS}_{\mathrm{TA}} \mathrm{f}^{\mathrm{f}}$ & $15.7 \pm 0.5$ & $12.8 \pm 0.4$ & $27.8 \pm 1.3$ & $28.8 \pm 0.7$ & $36.3 \pm 1.9$ & $34 \pm 3$ & $41 \pm 2$ & $39 \pm 3$ & & \\
\hline \multicolumn{12}{|l|}{ Compounds } \\
\hline violaxanthin like structure ${ }^{g}$ & & $5 \pm 2 d^{h}$ & $21 \pm 6 \mathrm{bc}$ & $39 \pm 9 a$ & $25 \pm 7 \mathrm{abc}$ & $35 \pm 7 \mathrm{ab}$ & $22 \pm 6 b c$ & $30 \pm 6 \mathrm{abc}$ & $17 \pm 5 c d$ & & \\
\hline violaxanthing & & $31 \pm 19 \mathrm{~d}$ & $144 \pm 6 a b$ & $160 \pm 30 a$ & $129 \pm 9 a b$ & $154 \pm 18 \mathrm{ab}$ & $115 \pm 17 b c$ & $132 \pm 15 \mathrm{ab}$ & $87 \pm 12 c$ & & \\
\hline$\left(8^{\prime} \mathrm{R}\right)$-neochrome ${ }^{i}$ & & $\operatorname{tr}$ & tr & tr & $3.2 \pm 0.5$ & tr & tr & tr & $\operatorname{tr}$ & & \\
\hline (9'Z)-neoxanthin ${ }^{i}$ & & $4.7 \pm 1.4 \mathrm{~d}$ & $50 \pm 15 \mathrm{ab}$ & $56 \pm 15 \mathrm{ab}$ & $72 \pm 17 \mathrm{a}$ & $45 \pm 11 \mathrm{~b}$ & $19 \pm 5 \mathrm{~cd}$ & $39 \pm 9 \mathrm{bc}$ & $15 \pm 4 \mathrm{~cd}$ & & \\
\hline$\left(8^{\prime} S\right)$-neochrome ${ }^{i}$ & & $10 \pm 3 a$ & $3.4 \pm 1.6 \mathrm{~b}$ & $2.3 \pm 0.6 \mathrm{~b}$ & $5.3 \pm 1.3 \mathrm{~b}$ & $3.5 \pm 1.2 \mathrm{~b}$ & $3.3 \pm 0.7 \mathrm{~b}$ & $3.0 \pm 1.0 \mathrm{~b}$ & $2.5 \pm 0.5 \mathrm{~b}$ & & \\
\hline 5,6-epoxy-lutein ${ }^{l}$ & & $33 \pm 13 d$ & $79 \pm 9 \mathrm{abc}$ & $100 \pm 20 \mathrm{ab}$ & $94 \pm 14 \mathrm{ab}$ & $104 \pm 10 \mathrm{a}$ & $74 \pm 7 \mathrm{bc}$ & $89 \pm 8 \mathrm{ab}$ & $56 \pm 5 c d$ & & \\
\hline luteoxanthing & & $6 \pm 2$ & $\operatorname{tr}$ & $\operatorname{tr}$ & $\operatorname{tr}$ & $\operatorname{tr}$ & $\operatorname{tr}$ & $\operatorname{tr}$ & $\operatorname{tr}$ & & \\
\hline lutein like structure ${ }^{m}$ & & $18 \pm 12 \mathrm{~d}$ & $86 \pm 12 a$ & $74 \pm 13 \mathrm{ab}$ & $69 \pm 8 \mathrm{ab}$ & $61 \pm 10 \mathrm{~b}$ & $36 \pm 4 \mathrm{~cd}$ & $52 \pm 9 b c$ & $28 \pm 3 d$ & & \\
\hline$Z$ lutein like structure ${ }^{m}$ & & $\operatorname{tr}$ & $19 \pm 2 \mathrm{ab}$ & $25 \pm 2 a$ & $18 \pm 4 \mathrm{ab}$ & $24 \pm 5 a$ & $18 \pm 4 a b$ & $21 \pm 4 a b$ & $14 \pm 3 b$ & & \\
\hline$\left(8^{\prime} \mathrm{S}\right)$-auroxanthin ${ }^{g}$ & & $16 \pm 3 a$ & $11 \pm 2 \mathrm{abc}$ & $10 \pm 5 a b c$ & $15 \pm 5 \mathrm{ab}$ & $12.3 \pm 1.3 \mathrm{abc}$ & $8.1 \pm 1.5 \mathrm{bc}$ & $10.5 \pm 1.1 \mathrm{abc}$ & $6.1 \pm 1.1 \mathrm{c}$ & & \\
\hline (all-E)-lutein ${ }^{m}$ & & $250 \pm 110 \mathrm{~d}$ & $610 \pm 90 \mathrm{a}$ & $610 \pm 80 \mathrm{a}$ & $610 \pm 70 \mathrm{a}$ & $480 \pm 40 \mathrm{ab}$ & $329 \pm 19 \mathrm{~cd}$ & $410 \pm 30 \mathrm{bc}$ & $249 \pm 14 \mathrm{~d}$ & & \\
\hline zeaxanthin $^{n}$ & & $30 \pm 20 c$ & $110 \pm 20 \mathrm{a}$ & $68 \pm 16 b$ & $64 \pm 6 \mathrm{~b}$ & $39 \pm 12 \mathrm{bc}$ & $18 \pm 3 c$ & $33 \pm 10 \mathrm{c}$ & $13 \pm 2 c$ & & \\
\hline (9Z)-lutein ${ }^{m}$ & & $9 \pm 7 \mathrm{bc}$ & $27 \pm 4 \mathrm{a}$ & $26 \pm 6 a$ & $20 \pm 3 a b$ & $15 \pm 6 b c$ & $7 \pm 5 c$ & $13 \pm 5 b c$ & $5 \pm 4 \mathrm{c}$ & & \\
\hline$\beta$-carotene ${ }^{o}$ & & $170 \pm 110 \mathrm{c}$ & $320 \pm 40 \mathrm{~b}$ & $380 \pm 80 \mathrm{ab}$ & $460 \pm 70 \mathrm{ab}$ & $497 \pm 19 a$ & $480 \pm 40 \mathrm{ab}$ & $426 \pm 17 \mathrm{ab}$ & $370 \pm 30 \mathrm{ab}$ & & \\
\hline$(9 Z)-\beta$-carotene ${ }^{o}$ & & $69 \pm 4$ & $51 \pm 6$ & $57 \pm 10$ & $52 \pm 11$ & $48 \pm 6$ & $51 \pm 11$ & $41 \pm 5$ & $39 \pm 9$ & & \\
\hline Total $^{p}$ & & $700 \pm 300 \mathrm{~d}$ & $1500 \pm 180 \mathrm{ab}$ & $1600 \pm 200 \mathrm{a}$ & $1640 \pm 120 \mathrm{a}$ & $1520 \pm 80 \mathrm{ab}$ & $1190 \pm 80 \mathrm{bc}$ & $1310 \pm 70 \mathrm{ab}$ & $900 \pm 60 \mathrm{~cd}$ & $290 \pm 300$ & $740 \pm 180$ \\
\hline
\end{tabular}

${ }^{a}$ Difference of total carotenoid concentrations between véraison and maturity; ${ }^{b}$ Total soluble solids are expressed in $\mathrm{g} / \mathrm{L} \cdot{ }^{c}$ Means of three replicates: ${ }^{d}$ Standard deviation at $p \leq 0.05 \cdot{ }^{e}$ Total acidity expressed in $\mathrm{g} / \mathrm{L}$ as tartaric acid $f^{f}$ Maturation index; ${ }^{g}$ Expressed as violaxanthin equivalent, ${ }^{h}$ Different letters in the same line are significantly different at the $5 \%$ level (Tukey's Honestly Significant Difference test ) ${ }^{i}$ Expressed as ( $9^{\prime} Z$ )-neoxanthin equivalent; ${ }^{l}$ Expressed as 5,6-epoxy-lutein equivalent; ${ }^{m}$ Expressed as (allE)-lutein equivalent; ${ }^{n}$ Expressed as zeaxanthin equivalent; ${ }^{o}$ Expressed as $\beta$-carotene equivalent; ${ }^{p}$ Sum of identified carotenoids. ${ }^{*}$ véraison: phenologic phase $10 \%$ of berries softening and/or coloring; because of the experimental drawback mentioned in the text, it was considered at the second sampling point. tr: present at concentration lower than LOQ. 

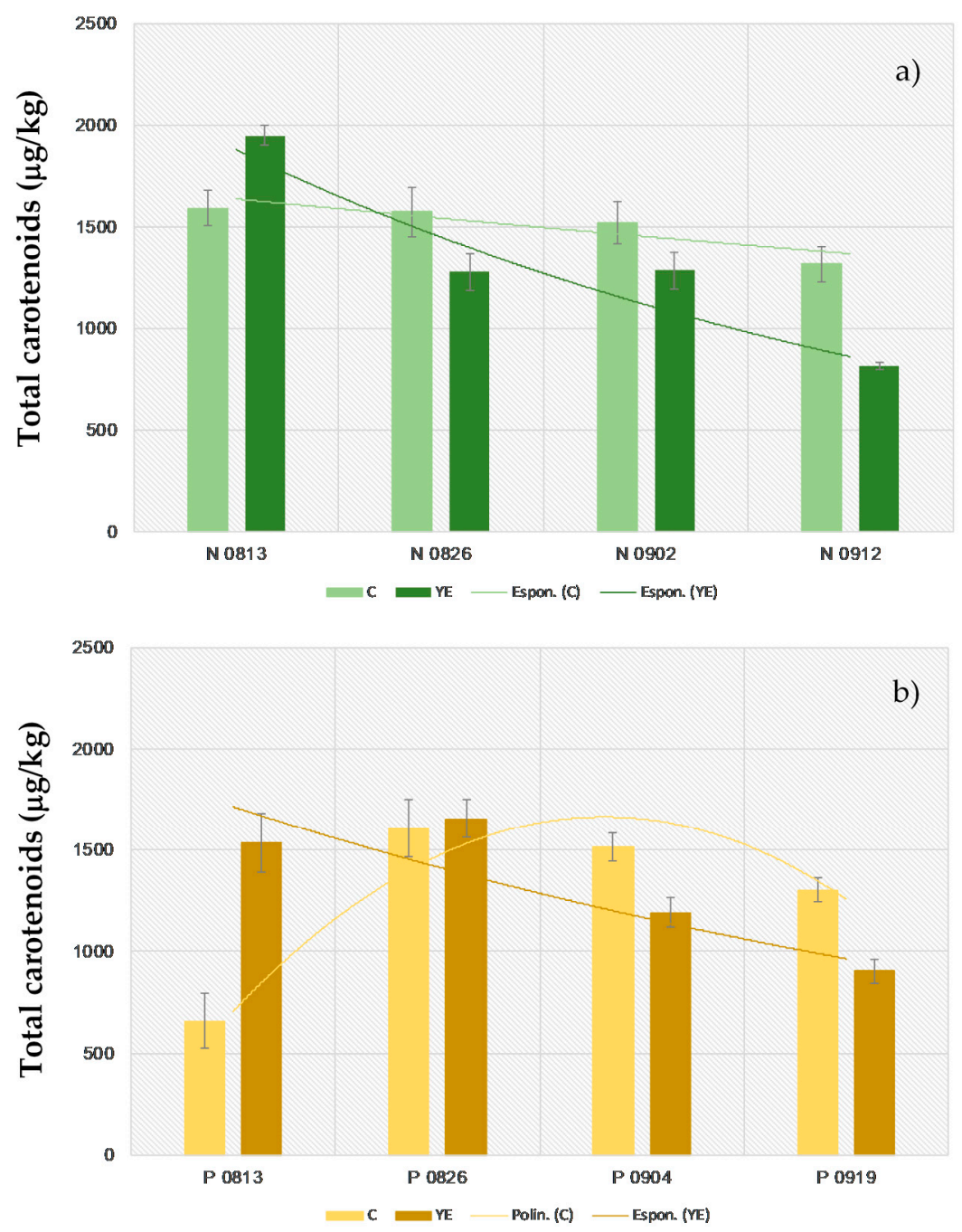

Figure 4. Total carotenoid variation in yeast extract-treated (YE) and control (C) Negro Amaro (a) and Primitivo (b) wine grapes during ripening.

$\beta$-carotene and (allE)-lutein were the main compounds in terms of concentration in all analyzed samples. The xanthophyll level was reduced more drastically than the carotene level, reaching values down to $60 \%-70 \%$ in mature grapes compared to the setting (Tables 2 and 3). Moreover, our data clearly showed that the at-harvest $\beta$-carotene content was greater than lutein in both varieties, which was in accordance with our previous report [7]. Geographic origin is recognized to affect the relative (allE)-lutein and $\beta$-carotene contents [2]. In some regions (northern Spain and southern Italy), $\beta$-carotene prevailed in grapes at maturity $[7,20]$ in contrast to other cultural situations (northern Italy and southern France) in which the xanthophyll level was higher than the carotene level $[1,3]$.

The interaction between treatment and ripening was very significant for lutein variation $(p<0.001)$ in both varieties (Figure 5a). YE-treated grapes showed an enhanced content of lutein only at véraison; then, they had lower levels in the following samples until reaching $200 \mu \mathrm{g} / \mathrm{kg}$ and $249 \mu \mathrm{g} / \mathrm{kg}$ of berries in Negro Amaro and Primitivo, respectively (Tables 2 and 3). An oscillating trend was observed in the case of $\beta$-carotene (Figure $5 b$ ). YE treatment conditioned the level of variation of this carotenoid less homogenously in Negro Amaro (TxR: $\mathrm{F}=5.04, p=0.008$ ) and, especially, in Primitivo (TxR: F = 4.43, $p=0.013)$. However, a common reduction of the compound between $Y E(270 \mu \mathrm{g} / \mathrm{kg}$ and $370 \mu \mathrm{g} / \mathrm{kg})$ and control samples $(470 \mu \mathrm{g} / \mathrm{kg}$ and $426 \mu \mathrm{g} / \mathrm{kg}$ ) was recorded in both cultivars (Tables 2 and 3). These findings were in disagreement with those of Gutierrez-Gamboa et al., 2018 [20], who reported that $Y E$ foliar application triggered $\beta$-carotene and lutein accumulation in mature grapes; however, they studied its effect on different varieties (Tempranillo, Graciano, and Garnacha). 

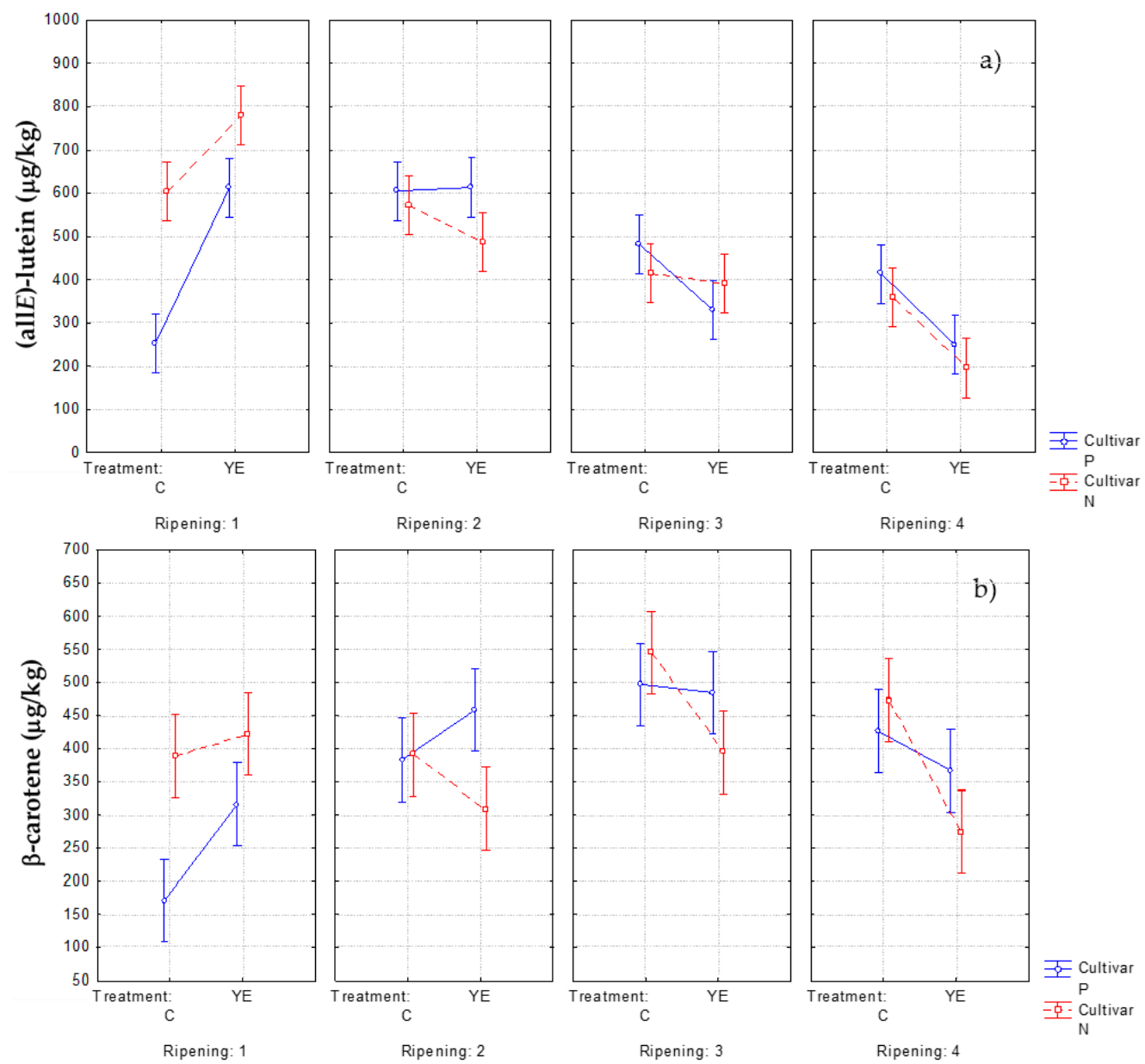

Figure 5. (allE)-lutein (a) and $\beta$-carotene (b) contents in yeast extract-treated (YE) and control (C) Negro Amaro and Primitivo wine grapes during ripening.

Finally, concerning the identified 5,6-epoxyxanthophylls, the data confirmed the difficulty of defining the border between the end of storage and the beginning of degradation, mainly in the case of 5,6-epoxylutein (Figure 6c) [7]. Nevertheless, the elicitor treatment caused a significant reduction in the concentrations of violaxanthin, $\left(9^{\prime} Z\right)$-neoxanthin, and 5,6-epoxylutein, as particularly evident in the two last sampling dates of Primitivo grapes (Figure 6; Tables 2 and 3).
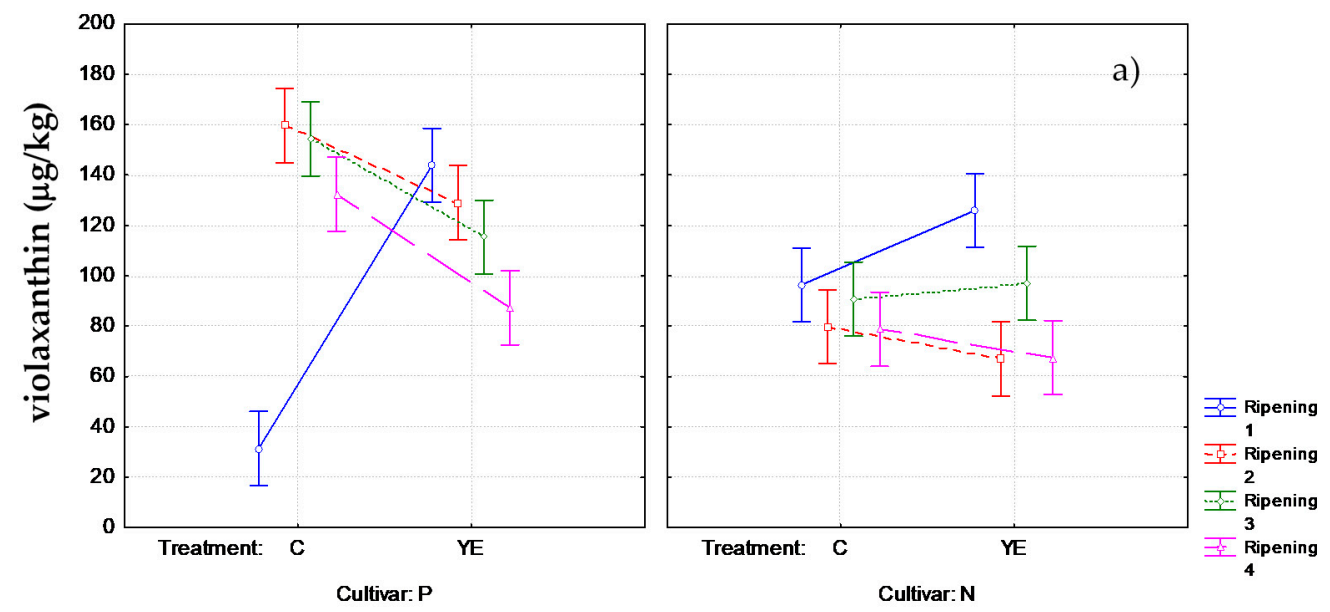

Figure 6. Cont. 

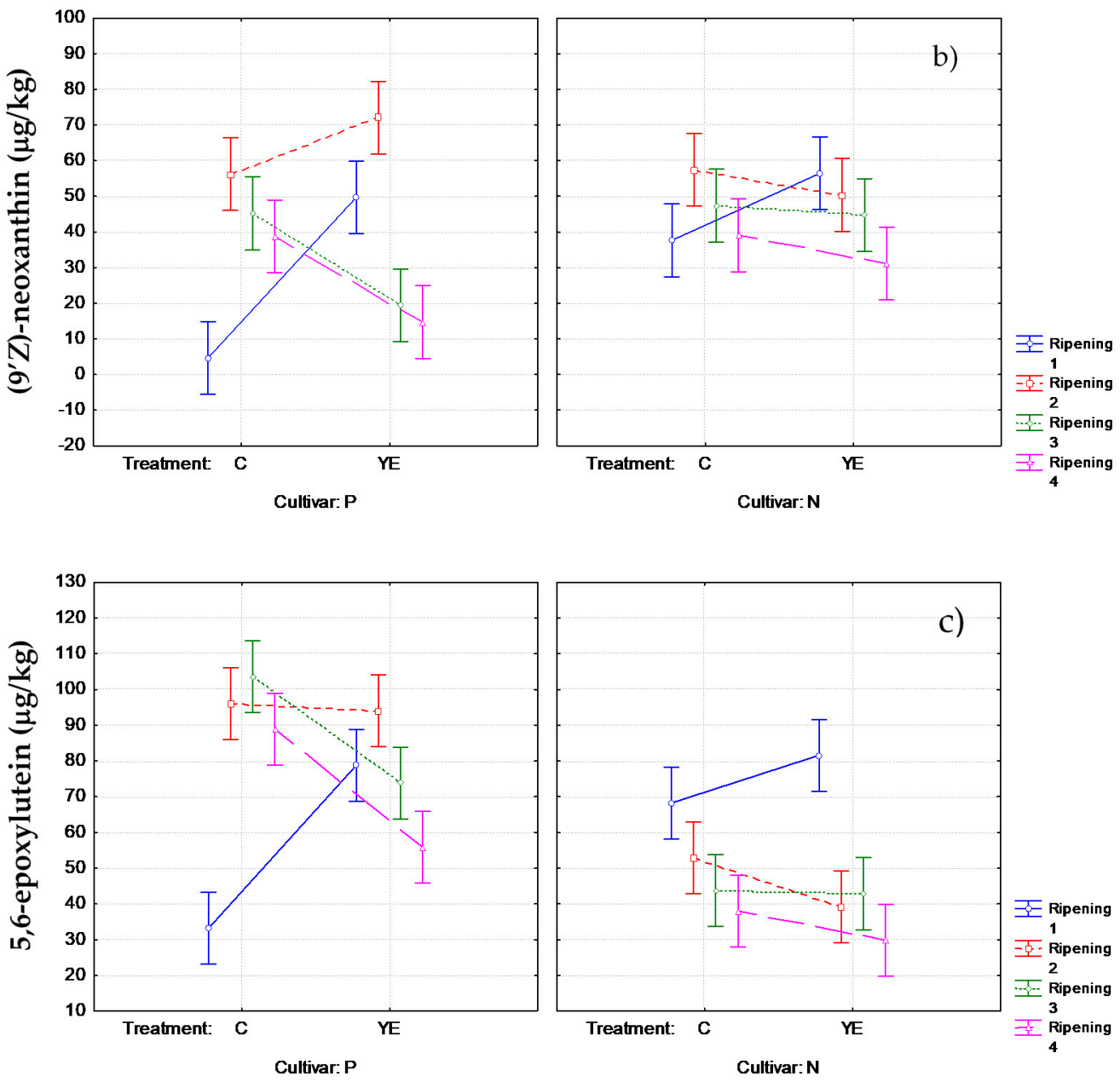

Figure 6. Violaxanthin (a), (9' Z)-neoxanthin (b), and 5,6-epoxylutein (c) contents in yeast extract-treated (YE) and control (C) Negro Amaro and Primitivo wine grapes during ripening.

\subsection{Influence of YE Treatment on the Norisoprenoid Aroma Potential $(\Delta C)$}

As accepted, $\mathrm{C}_{13}$-norisoprenoid varietal aroma in wine grapes is strictly related to carotenoid degradation during ripening [5,29]. Therefore, determining the difference of total carotenoids between véraison and harvest points $(\Delta C)$ together with their decreasing kinetics can be a useful tool for defining the aroma potentiality of grapes for wine making [7]. On the other side, elicitor treatment by foliar application in vineyards has proved to influence the development of aroma compounds in wines [19]; in particular, grapevines treated with benzothiadiazole have been shown to increase the concentrations of some $\mathrm{C}_{13}$-norisoprenoids, such as $\beta$-damascenone and $\beta$-ionone, while the use of methyl jasmonate did not alter their content [30].

In our work, a similar change in norisoprenoid aroma potential was shown by control samples of Negro Amaro and Primitivo, with $\Delta C$ values of $270 \mu \mathrm{g} / \mathrm{kg}$ and $290 \mu \mathrm{g} / \mathrm{kg}$, respectively (Tables 2 and 3). This finding was in agreement with data from a 3 year-long study conducted on the same cultivars in Apulia [7]. Moreover, the YE treatment significantly affected the aroma potential of the grapes, increasing the $\Delta C s 2.6$ and 4.2-fold in Primitivo $(740 \mu \mathrm{g} / \mathrm{kg})$ and Negro Amaro $(1130 \mu \mathrm{g} / \mathrm{kg})$, respectively (Tables 2 and 3). In the literature, it is well documented that the use of elicitors (i.e., methyl jasmonate, chitosan, yeast extracts) stimulates plant defense mechanisms and consequently activates the enzymes responsible for the biosynthesis of secondary metabolites, such as phenolic compounds [16,31]. YE caused an accumulation of anthocyanins, stilbenes, and flavonoids in wine grapes without varying their phenological maturation $[18,32,33]$. Since there was no significant difference in maturation indexes between YE and C samples (Tables 2 and 3), the effect of treatment 
on $\Delta C$ variation could be attributed to the activation of enzymes catalyzing either the biosynthesis of carotenoids (as proved by the highest values being in YE grapes at véraison) or their degradation (as confirmed by the lowest values being in YE grapes at harvest) (Figure 4).

The knowledge of the carotenoid profile of grapes is linked to the type of norisoprenoid compound which will form in wine. $\beta$-ionone is derived from $\beta$-carotene oxidation, whereas 3 -hydroxy- $\alpha$-ionone and 3-oxo- $\alpha$-ionol originate by lutein cleavage [11,12]. The factor score plot (accounting for $82.06 \%$ of total variance) from the PCA performed on the variables corresponding to the difference of the identified carotenoid level between véraison and harvest in both YE and $C$ grape samples is shown in Figure 7. This clearly shows that YE-treated grapes of Negro Amaro and Primitivo were different from $\mathrm{C}$ samples along $\mathrm{PC}_{1}$ and $\mathrm{PC}_{2}$, respectively, and they were more correlated to carotenoid-derivative variables. Furthermore, NYE was mainly characterized by lutein, $\beta$-carotene, and violaxanthin derivatives (factor coordinates: $-0.9535,-0.8657$, and -0.8643 , respectively, onto $\mathrm{PC}_{1}$ ), while PYE was principally characterized by a higher concentration of $\left(9^{\prime} \mathrm{Z}\right)$-neoxanthin derivatives (factor coordinate: -0.8492 onto $\mathrm{PC}_{2}$ ) (Figure 7).

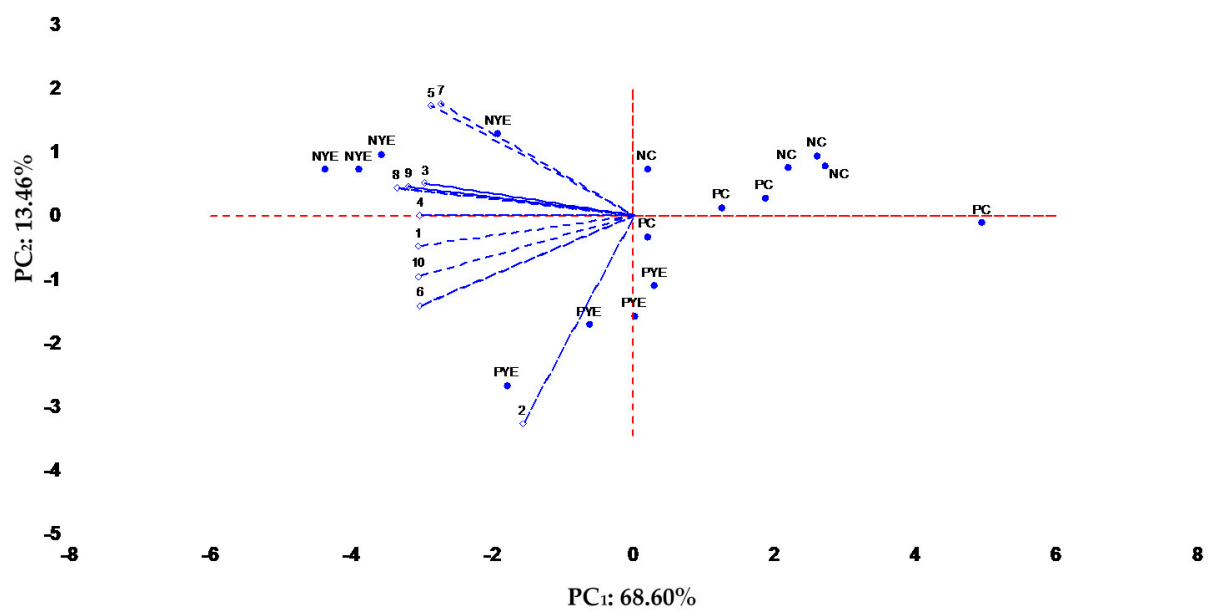

Figure 7. Principal component diagram of carotenoid derivatives in the two grape varieties (N: Negro Amaro; P: Primitivo) as affected by the treatment (C: control; YE: yeast extract). 1, violaxanthin derivative; 2, (9'Z)-neoxanthin derivative; 3, (8'S)-neochrome derivative; 4, 5,6-epoxylutein derivative; 5 , luteoxanthin derivative; 6 , lutein like structure derivative; 7 , Z-lutein like structure derivative; 8 , (allE)-lutein derivative; 9, (9Z)-lutein derivative; 10, $\beta$-carotene derivative.

\section{Conclusions}

Fifteen carotenoids, including (allE)-lutein and $\beta$-carotene together with their $9 \mathrm{Z}$ isomers and 5,6-/5,8-epoxyxanthophylls, were tentatively identified by matching UV-Vis characteristics, MS spectra, and elution order, and were accurately quantified by the used analytical method. As expected, a decrease of carotenoids during ripening was observed in both the two cultivars, but this was even more noticeable in grapes treated with YE. $\beta$-carotene and (allE)-lutein were present as the main compounds in all the analyzed samples, and the level of xanthophyll appeared to be more drastically reduced than the carotene level, especially in mature Negro Amaro and Primitivo treated grapes. Similarly, the elicitor treatment caused a more consistent decrease of violaxanthin, (9'Z)-neoxanthin, and 5,6-epoxylutein.

Thereby, because carotenoids serve as precursors of $C_{13}$-norisoprenoids, the YE treatment proved to be determinant in enhancing the aroma potential $(\Delta C)$ of both varieties up to four-fold compared to untreated grapes. Besides this, Negro Amaro and Primitivo were principally characterized by lutein, $\beta$-carotene, and violaxanthin derivatives, and ( $\left.9^{\prime} Z\right)$-neoxanthin derivatives, respectively. However, further research is ongoing to confirm the real characteristics of these grapes in obtaining wines which are richer in sensorial impact $C_{13}$ aroma compounds, such as $\beta$-ionone and $\beta$-damascenone. 
Supplementary Materials: The following are available online at http://www.mdpi.com/2076-3417/10/10/3369/s1, Figure S1: Extraction yields of (a) Negro Amaro and (b) Primitivo samples, Table S1: Validation parameters, linearity, repeatability (r), LOD and LOQ for HPLC-DAD analyses.

Author Contributions: Conceptualization, P.C.; methodology, G.M., A.R.C. and L.T.; validation, P.C. and M.S.; formal analysis, M.S.; data curation, P.C.; writing — original draft preparation, P.C.; writing-review and editing, F.V. and F.A.T.-B.; visualization, F.B. All authors have read and agreed to the published version of the manuscript.

Funding: This research received no external funding.

Acknowledgments: We would like to thank LALLEMAND Italia S.p.A. for supplying the Lalvigne ${ }^{\circledR}$ MATURE formulation used in this work.

Conflicts of Interest: The authors declare no conflict of interest. LALLEMAND had no role in the design of the study; in the collection, analyses, or interpretation of data; in the writing of the manuscript, or in the decision to publish the results.

\section{References}

1. Razungles, A.; Babic, I.; Sapis, J.C.; Bayonove, C.L. Particolar behavior of epoxy xanthophylls during veraison and maturation of grape. J. Agric. Food Chem. 1996, 44, 3821-3825. [CrossRef]

2. Razungles, A.; Bayonove, C.L.; Cordonnier, R.E.; Baumes, R.L. Etude des Carotenoides du Raisin à Maturitè. Vitis 1987, 26, 183-191.

3. Razungles, A.; Bayonove, C.L.; Cordonnier, R.E.; Sapis, J.C. Grape carotenoides: Changes during the maturation period and localization in mature berries. Am. J. Enol. Vitic. 1988, 39, 44-48.

4. Crupi, P.; Milella, R.A.; Antonacci, D. Simultaneous HPLC-DAD-MS (ESI+) determination of structural and geometrical isomers of carotenoids in mature grapes. J. Mass Spectrom. 2010, 45, 971-980. [CrossRef] [PubMed]

5. Mendes-Pinto, M.M.; Silva-Ferreira, A.C.; Caris-Veyrat, C.; Guedes de Pinho, P. Carotenoid, chlorophyll, and chlorophyll-derived compounds in grapes and port wines. J. Agric. Food Chem. 2005, 53, 10034-10041. [CrossRef] [PubMed]

6. Silva-Ferreira, A.C.; Monteiro, J.; Oliveira, C.; Guedes de Pinho, P. Study of major aromatic compounds in port wines from carotenoid degradation. Food Chem. 2008, 110, 83-87. [CrossRef]

7. Crupi, P.; Coletta, A.; Milella, R.A.; Palmisano, G.; Baiano, A.; La Notte, E.; Antonacci, D. Carotenoid and Chlorophyll derived compounds in some wine grapes grown in Apulian region. J. Food Sci. 2010, 75, S191-S198. [CrossRef]

8. Azevedo-Meleiro, C.H.; Rodriguez-Amaya, D.B. Confirmation of the identity of the carotenoids of tropical fruits by HPLC-DAD and HPLC-MS. J. Food Compos. Anal. 2004, 17, 385-396. [CrossRef]

9. Crupi, P.; Alba, V.; Masi, G.; Caputo, A.R.; Tarricone, L. Effect of two exogenous plant growth regulators on the color and quality parameters of seedless table grape berries. Food Res. Int. 2019, 126, 108667. [CrossRef]

10. Baumes, R. Wine aroma precursors. In Wine chemistry and biochemistry; Moreno-Arribas, M.V., Polo, M.C., Eds.; Springer: New York, NY, USA, 2009; pp. 251-274.

11. Crupi, P.; Coletta, A.; Antonacci, D. Analysis of carotenoids in grapes to predict norisoprenoid varietal aroma of wines from Apulia. J. Agric. Food Chem. 2010, 58, 9647-9656. [CrossRef]

12. Baumes, R.; Wirth, J.; Bureau, S.; Gunata, Y.; Razungles, A. Biogeneration of C13-norisoprenoid compounds: Experiments supportive for an apo-carotenoid pathway in grapevines. Anal. Chim Acta 2002, 458, 3-14. [CrossRef]

13. Oliveira, C.; Silva Ferreira, A.C.; Mendes Pinto, M.; Hogg, T.; Alves, F. Carotenoid compounds in grapes and their relationship to plant water status. J. Agric. Food Chem. 2003, 51, 5967-5971. [CrossRef] [PubMed]

14. van Breemen, R.B. Liquid chromatography/mass spectrometry of carotenoids. Pure App. Chem. 1997,69, 2061-2066. [CrossRef]

15. Emenhiser, C.; Simunovic, N.; Sander, L.C.; Schwartz, S.J. Separation of geometrical carotenoid isomers in biological extracts using a polymeric C30 column in reversed-phase liquid chromatography. J. Agric. Food Chem. 1996, 44, 3887-3893. [CrossRef] 
16. Ferrari, S. Biological elicitors of plant secondary metabolites: Mode of action and use in the production of nutraceutic. In Bio-Farms for Nutraceuticals: Functional Food and Safety Control by Biosensors; Giardi, M.T., Rea, G., Berra, B., Eds.; Landes Bioscience and Springer Science + Business Media LLC: New York, NY, USA, 2010; pp. 152-166.

17. Bektas, Y.; Eulgem, T. Synthetic plant defense elicitors. Front. Plant Sci. 2015, 5, 1-17. [CrossRef]

18. Portu, J.; López, R.; Baroja, E.; Santamaría, P.; Garde-Cerdán, T. Improvement of grape and wine phenolic content by foliar application to grapevine of three different elicitors: Methyl jasmonate, chitosan, and yeast extract. Food Chem. 2016, 201, 213-221. [CrossRef]

19. Šuklje, K.; Antalick, G.; Buica, A.; Coetzee, Z.A.; Brand, J.; Schmidtke, L.M.; Vivier, M.A. Inactive dry yeast application on grapes modify Sauvignon Blanc wine aroma. Food Chem. 2016, 197, 1073-1084. [CrossRef]

20. Gutiérrez-Gamboa, G.; Marín-San Román, S.; Jofré, V.; Rubio-Bretón, P.; Pérez-Álvarez, E.P.; Garde-Cerdán, T. Effects on chlorophyll and carotenoid contents in different grape varieties (Vitis vinifera L.) after nitrogen and elicitor foliar applications to the vineyard. Food Chem. 2018, 269, 380-386. [CrossRef]

21. Betz, M.; Schindler, C.; Schwender, J.; Lichtenthaler, H.K. Jasmonic acid induced changes in carotenoid levels and zeaxanthin cycle performance. In Plant Lipid Metabolism; Kader, J.C., Mazliak, P., Eds.; Springer: Dordrecht, The Netherlands, 1995; pp. 353-355.

22. Lu, Y.; Jiang, P.; Liu, S.; Gan, Q.; Cui, H.; Quin, S. Methyl jasmonate- or gibberellins A3-induced astaxanthin accumulation is associated with up-regulation of transcription of $\beta$-carotene ketolase genes (bkts) in microalga Haematococcus pluvialis. Bioresour. Technol. 2010, 101, 6468-6474. [CrossRef]

23. Office International de la Vigne et du Vin (OIV). Recueil des Methodes Internationales d'Analyse des Vins et des Mouts; Office International de la Vigne et du Vin: Paris, France, 1990.

24. Melendez-Martinez, A.J.; Britton, G.; Vicario, I.M.; Heredia, F.J. HPLC analysis of geometrical isomers of lutein epoxide isolated from dandelion (Taraxacum officinale F.Weber exWiggers). Phytochemistry 2006, 67, 771-777. [CrossRef]

25. Martì, M.P.; Busto, O.; Guash, J. Application of a headspace mass spectrometry system to the differentiation and classification of wines according to their origin, variety and ageing. J. Chromatogr. A 2004, 1057, $211-217$. [CrossRef] [PubMed]

26. Oliver, J.; Palou, A. Chromatographic determination of carotenoids in foods. J. Chromatogr. A 2000, 881, 543-555. [CrossRef]

27. Bureau, S.M.; Razungles, A.J.; Baumes, R.L.; Bayonove, C.L. Effect of vine or bunch shading on the carotenoid composition in Vitis Vinifera L. berries. I. Syrah grapes. Vitic. Enol. Sci. 1998, 53, 64-71.

28. González-Gómez, D.; Lozano, M.; Fernández-León, M.F.; Bernalte, M.J.; Ayuso, M.C.; Rodríguez, A.B. Sweet cherry phytochemicals: Identification and characterization by HPLC-DAD/ESI-MS in six sweet cherry cultivars grown in Valle del Jerte (Spain). J. Food Compos. Anal. 2010, 23, 533-539. [CrossRef]

29. Oliveira, C.; Barbosa, A.; Silva Ferreira, A.C.; Guerra, J.; Guedes De Pinho, P. Carotenoid profile in grapes related to aromatic compounds in wines from Douro region. J. Food Sci. 2006, 71, S1-S7. [CrossRef]

30. Gómez-Plaza, E.; Mestre-Ortuño, L.; Ruiz García, Y.; Fernández-Fernández, J.I.; López-Roca, J.M. Effect of benzothiadiazole and methyl jasmonate on the volatile compound composition of Vitis vinifera L. Monastrell grapes and wines. Am. J. Enol. Vitic. 2012, 63, 394-401. [CrossRef]

31. Lucini, L.; Baccolo, G.; Rouphael, Y.; Colla, G.; Bavaresco, L.; Trevisan, M. Chitosan treatment elicited defence mechanisms, pentacyclic triterpenoids and stilbene accumulation in grape (Vitis vinifera L.) bunches. Phytochemistry 2018, 156, 1-8. [CrossRef]

32. Kogkou, C.; Chorti, E.; Kyraleou, M.; Kallithraka, S.; Koundouras, S.; Logan, G.; Kanakis, I.; Kotseridis, Y. Effects of foliar application of inactivated yeast on the phenolic composition of Vitis vinifera L. cv. Agiorgitiko grapes under different irrigation level. Int. J. Wine Res. 2017, 9, 23-33. [CrossRef]

33. Paladines-Quezada, D.F.; Fernández-Fernández, J.I.; Bautista-Ortín, A.B.; Gómez-Plaza, E.; Bleda-Sánchez, J.A.; Gil-Muñoz, R. Influence of the use of elicitors over the composition of cell wall grapes. In Proceedings of the In Vino Analytica Scientia 2017, Salamanca, Spain, 17-20 July 2017.

(C) 2020 by the authors. Licensee MDPI, Basel, Switzerland. This article is an open access article distributed under the terms and conditions of the Creative Commons Attribution (CC BY) license (http://creativecommons.org/licenses/by/4.0/). 